\title{
HONFOGLALÁS KORI SÍR TISZAPÜSPÖKI HATÁRÁBAN
}

\author{
FODOR ISTVÁN-KERTÉSZ RÓBERT*
}

\begin{abstract}
A female burial of the Conquest period came to light on the outskirts of Tiszapüspöki, a settlement lying north of Szolnok, during the salvage excavations preceding the construction of the M4 Motorway. The west to east oriented burial was disturbed by a ditch and during the mechanical humus removal. Lying beside the skeletal remains were a pair of tinned bronze braid ornaments, a bracelet of sheet bronze, beads, the fragment of an iron awl and a bone bead. The burial and its finds can be dated to the 10th century.
\end{abstract}

Keywords: Tiszapüspöki, 10th-century female burial, braid ornaments

A Szolnoktól északra fekvő Tiszapüspöki határának délkeleti kiszögellésében, az M4-es autópálya épitésének megelőző régészeti ásatása során honfoglalás kori női sír került napvilágra. A nyugatkeleti tájolású sírt egy korábbi árokkal és a gépi humuszolással megbolygatták. A fiatal nő váza mellett ónozott bronz hajfonatdíszitö korongpár, bronz lemezkarperec, gyöngyök, vasár töredéke és csontgyöngy feküdtek. A mellékletek a 10. századra keltezhetök.

Kulcsszavak: Tiszapüspöki, 10. századi női temetkezés, hajfonatdiszitő korongok

A tervezett M4-es autópálya Abony és Fegyvernek közötti szakaszán az elmúlt évben a szolnoki Damjanich János Múzeum régészei végeztek megelőző régészeti feltárást. Tiszapüspöki határának délkeleti részén, közvetlenül a törökszentmiklósi határ mellett található a Háromág-dúló, amely onnan kapta a nevét, hogy a Tisza szabályozása előtt itt szakadt a Tinókába a Fehértó-ér és egy névtelen kis vízfolyás. Az itt emelkedő hát állandóan vízmentes volt, a környező laposok pedig a hullámtérhez tartoztak, ezért korábban legelőnek használták ezt a területet. Ezen a ma-

A kézirat érkezett: 2015. június 3.

* Fodor István. Magyar Nemzeti Múzeum, 1088 Budapest, Múzeum krt. 14-16.; istvan.fodor@t-email.hu

Kertész Róbert. Damjanich János Múzeum, 5000 Szolnok, Kossuth tér 4.; kertesz@djm.hu gasparton állt a legutóbbi időkig Tóvizi Antal tanyája, csupán mintegy 800 méterre Törökszentmiklós városának attól a részétől, amelyet korábban Kisszőlőnek neveztek (1. kép). ${ }^{1}$

A kijelölt nyomvonal keleti végénél feküdt a feltárás Tiszapüspöki-Karancs-Háromág nevú, 19. számú lelőhelye, ahol több régészeti kor leletei kerültek elő, az újkőkortól a 18. századig. Az elkerülő út építése előtt, 1999-ben és 2000-ben a szolnoki múzeum munkatársai bronzkori és vaskori objektumokat tártak itt fel. ${ }^{2}$

A honfoglalás kori sír a humuszréteg gépi eltávolításakor a kijelölt nyomvonal északi határán, kissé már azon is átnyúlva került napvilágra, az egykori tanyaudvar déli szélén, 2014. augusztus

BENEDEK 2001, 33-34.

2 CSÁNYI-CSEH-TÁRNOKI 2002, 47-62. 

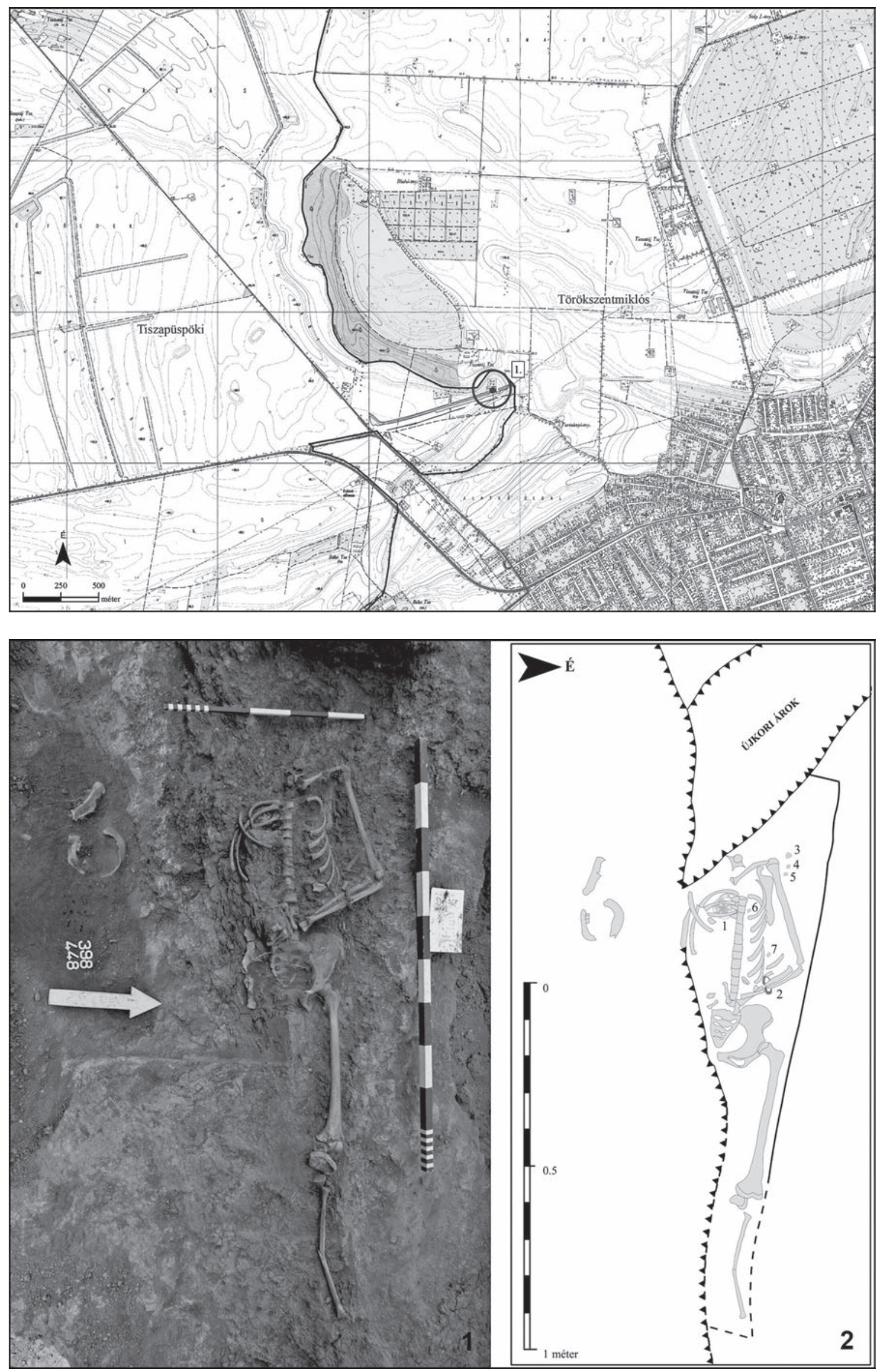


\section{1. kép (balra fent). A lelőhely}

Fig. 1. The site

2. kép (balra lent). 1: A sír (Hegedús Sándor felvétele); 2: A sír rajza. 1: korongok; 2: karperec; 3-7: gyöngyök

Fig. 2. 1: The grave (photo by Sándor Hegedús); 2: Plan of the grave. 1: braid ornaments; 2 . bracelet; $3-7$ : beads

11-én. A munkagép megbolygatta a váz jobb oldalát. A temetkezés egy Körös-kultúrához tartozó gödör betöltésében volt, ám a négyszögletes sírgödör foltja jól észlelhetően kirajzolódott (2. kép 2). A feltárók kezdetben úgy vélték, hogy a sír az őskori gödör betöltéséhez tartozik, ezért nem bontották ki közvetlenül előkerülése után, hanem csak szeptember 2-án és 4-én. A bontás alkalmával az is kiderült, hogy a sírt nem csupán a munkagép bolygatta meg, hanem korábban egy újkori árok is, amelynek ásásakor a koponyát eltávolították eredeti helyéről, de nem dobták ki, hanem az árok oldalába ásták (2. kép).

\section{A sír és a mellékletek leírása}

Juvenis (18-20 éves) nő nyugati tájolású váza egy kb. $170 \times 65 \mathrm{~cm}-e s$, téglalap alakú sírgödörben, amely a mai felszíntől $74 \mathrm{~cm}$ mélyen van. A roncsolt koponya a váztól $20 \mathrm{~cm}$-rel délebbre, $113 \mathrm{~cm}$ mélyen fekszik. A gépi bolygatás miatt a jobb kar, lapocka, medencelapát és láb csontjai hiányoznak, csakúgy, mint a bal sípcsont. Ugyanekkor mozdultak ki helyükról a jobb oldali bordák is. Mellékletek:

1. A jobb oldali bordák és kissé a csigolyák alatt került elő az ónozott felületú, bronzból öntött, egymás fölött elhelyezett, áttört, palmettadíszes korongpár (2. kép; 3. kép 1; 4. kép). Az egy öntőmintában készült két bronzkorong felületén ónozás nyomai látszanak. A korongok átmérője $5,7 \mathrm{~cm}$, vastagságuk $0,2 \mathrm{~cm}$. Átmetszetük kissé domborodó ívú. A 0,3 cm szélességú kereten belüli teret levélmintázat díszíti. A keret aljából alul egy három levélből álló csokor ágazik ki, amelynek levelei fölül egy négy levélből álló újabb csokorhoz csatlakoznak. Ez utóbbi leveleket kétoldalt egy-egy spirálban végződő inda fogja össze, fölül középütt pedig két, ugyancsak spirálban végződő levél csatlakozik a csokorhoz. A tárgyak felülete egyszerúen kidolgozott, de nem egyformán. A jobb oldalin a levelek spirálban való csatlakozását jóval gondosabban dolgozta ki az egykori mester, mint a bal oldalin, ahol ez a részlet két helyen is erősen elnagyolt. Ebből az eltérésból (a két öntvény felületének eltérő kidolgozásából) az is következhet, hogy a két korong nem egy idóben készült. ${ }^{3}$ A korongok sírbeli helyzetéból kiderül, hogy a temetéskor ezek függesztő szalagjai nem voltak a varkocsba fonva. A két varkocsdíszt a holttest alatt helyezték el a

3 Nem egyedülálló jelenség ez honfoglalás kori korongjaink esetében, hiszen biztosan különböző időben, más mester keze által készültek a híres rakamazi korongok is. Legutóbb ld. FODOR 2014, további irodalommal. sírgödörben, méghozzá eredeti állásukkal ellentétes irányban. Az elhunyt varkocsai aligha lehettek egymás fölött, mint ahogy általában a korongok sincsenek egymás fölött a sírokban. (A szalagot vagy szíjat minden bizonnyal a felső perem alatti áttörésbe fúzték be, alul pedig, a levélcsokor két oldalán színes szalagokkal díszíthették a korongokat.)

2. A has bal oldalán nyugvó bal alkarcsont középső részét bronzból készült lemezkarperec öleli, amelynek mindkét lekerekített vége ovális alakban kiszélesedik, és
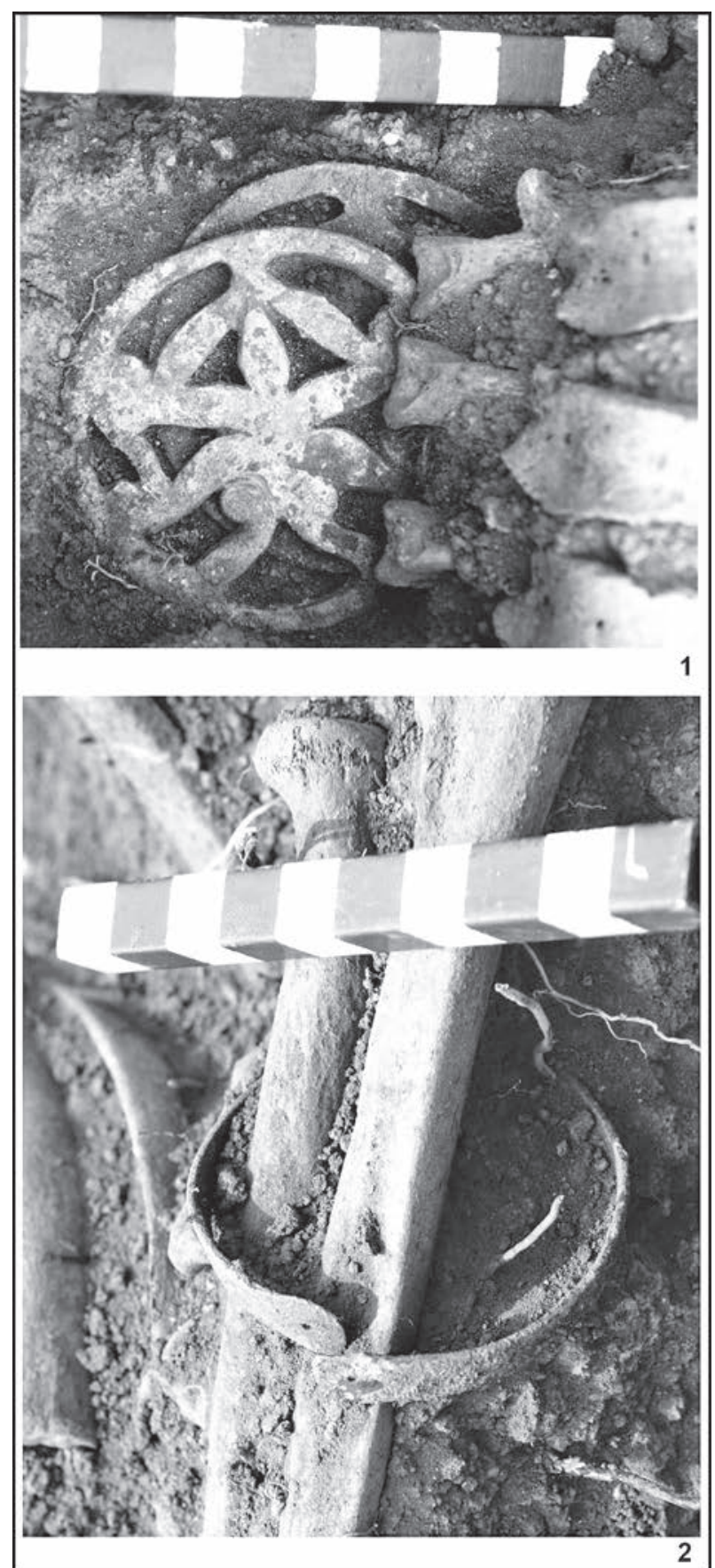

3. kép. 1: A korongpár a bordák felszedése után; 2: A karperec a karcsonton (Hegedûs Sándor felvételei)

Fig. 3. 1: The braid ornaments after the lifting of the ribs; 2: The bracelet on the arm bone (photos by Sándor Hegedús) 


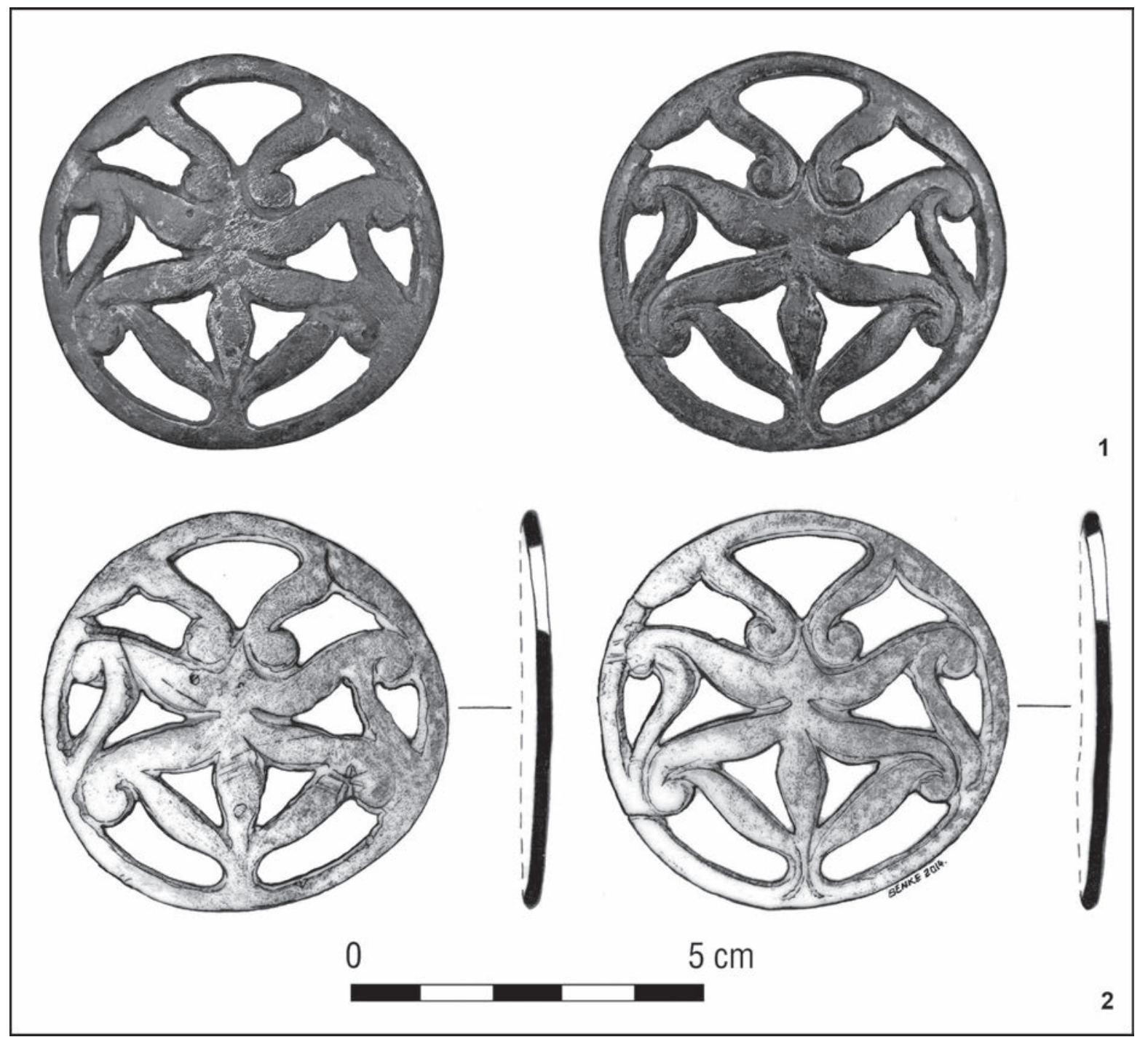

4. kép. A korongpár (Dabasi András felvétele; rajz: Benke Zsolt)

Fig. 4. The braid ornaments (photo by András Dabasi; drawing: Zsolt Benke)

egy-egy lyukkal át van ütve (3. kép 2; 5. kép 1). A karperec átmérője 5,6-5,7 cm, a bronzszalag szélessége $0,7 \mathrm{~cm}$, a végeinél $0,9 \mathrm{~cm}$, a pánt vastagsága $0,1 \mathrm{~cm}$. Mint annyi más lelőhelyen, itt is az igazolódott, hogy a pántkarpereceket a női ingek bő ujjainak összefogására használták. A mi példányunk két végét a lyukakon át egybekötötték.

3. A bal váll mellett és a bal oldali bordáknál apró gyöngyök kerültek elő. Közülük 52 db apró agyaggyöngy (átmérőjük 0,2-0,3 cm), $8 \mathrm{db}$ pedig fémes színú kagylóból készült gyöngy (átmérójük 0,5-0,6 cm) (5. kép 2).

A sír felszedésekor a csontváz maradványaitól nem nagy távolságban még a következő tárgyakat találták, amelyek esetleg a részben feldúlt temetkezéshez tartozhattak: vasár és hengeres csontgyöngy töredéke, továbbá két asztragalosz. Ez utóbbi, szórvány leletek közül az ár előfordul honfoglalás kori sírjainkban. Őseink hite szerint - mint hegyes szúró vastárgynak - bajelhárító szerepe volt. ${ }^{4}$ A hengeres csontgyöngy sem számít különös

4 Solymossy 1933. ritkaságnak köznépi temetőinkben. Annál inkább az asztragaloszok, amelyek az avar korban általánosak. Ezekről a leletekről azonban nem igazolható, hogy az ismertetett sírban voltak.

A női temetkezés viszonylag szerény mellékletei közül az ónozott felületú öntött bronz korongpár a leginkább figyelemre méltó. Az ónozott bronzkorongok nem ismeretlenek 10. századi emlékanyagunkban. Ilyen volt - amint erre Révész László felhívta a figyelmemet - a lemezes dormánd-hanyipusztai korongpár, ${ }^{5}$ továbbá ónozott (vagy ezüstözött) volt a felülete az ép szolnok-szandai korongnak is. ${ }^{6}$ Áttört korongjaink között azonban nem akadtam további óno-

RÉVÉSZ 2008, 76.

6 Madaras 2003, 279. 
zott példányokra. A tiszapüspöki darabok palmettás mustrájának pontos mását eddig ugyan szintén nem ismerem, de minden bizonnyal az ún. életfás díszú, áttört darabokhoz sorolhatók, amelyek kiemelkedő múvészi színvonalú példánya a sárospataki korongpár. ${ }^{7}$ Ez a tárgytípus szorosan kapcsolódik honfoglaló őseink hitvilágához. ${ }^{8} \mathrm{Az}$ itt közölt példányok kétségkívül magyar ízlésben fogantak, a 10. századi magyar múvészet honfoglalás után kialakult tárgytípusaihoz tartoznak, tehát aligha keltezhetők a honfoglalók elsó nemzedékéhez. Ugyanakkor az is valószínú, hogy még a 10. században készültek, meglehetősen szerény képességú mester múhelyében, az ősi magyar pogány hit jelképével. Ennél többet sajnos nem is mondhatunk a sír keltezéséről, mivel ahhoz a többi melléklet sem ad biztosabb támpontokat.

Mivel az ismertetett temetkezésen kívül több hasonló korú sír nem került elő a feltárt nyomvonal területén, nincs kizárva, hogy az ásatók egy magányos sírra bukkantak. Megítélésünk szerint azonban sokkal nagyobb az esélye annak, hogy a sírtól északra, a korábbi tanya udvarán további temetkezések, esetleg nagyobb sírszámú temetó is lehet. Erre ugyanis még elegendő hely van az árvízmentes kiemelkedésen. Nem is lenne haszontalan a terület megkutatása, hiszen Tiszapüspöki és Törökszentmiklós nagy határában eddig alig ismerünk honfoglalás kori leleteket. Tiszapüspöki község keleti szélén 1969-ben, a gázcsere-telep építésekor megsemmisítettek három-négy sírt, ahonnan csupán egy bronzgyưrú került be a szolnoki múzeumba. Ugyanez év októberének közepén Horváth Bélával végeztünk itt egynapos leletmentő ásatást, amelynek során három melléklet nélküli gyermeksírt találtunk. ${ }^{9}$ Törökszentmiklósról két lelóhelyet jegyzett fel Butyka Béla tanító, egykori helytörténész: a fentiekben ismertetett temetkezéstől mintegy 500 méterre északnyugatra, Hudu János földjén az 1950-es években övveret került elő szántáskor, a surjáni Tere-halom mellett pedig az egykori Tóth István-tanyán kengyelek láttak napvilágot. 1969ben mindkét lelőhelyen végeztem szondázó ásatást, ezek azonban nem vezettek eredményre. ${ }^{10}$ Régészek eddig egyetlen helyen, Szenttamáson tártak fel 10-11. századi sírokat. Egy kis homokdombon, gépi homokkitermelés során semmisítettek meg itt ismeretlen számú sírt. 1983-ban Laszlovszky József vezetésével a szolnoki múzeum régészei két alkalommal is végeztek lelet-

\footnotetext{
7 DIENES 1972, 104-105, 25. t. 6; FODOR 1996, 169-171.

8 Vö. DiÓsZeGI 1969; DiEnES 1980.

9 FODOR 1970a, 74

10 FODOR 1970b, 20.
}

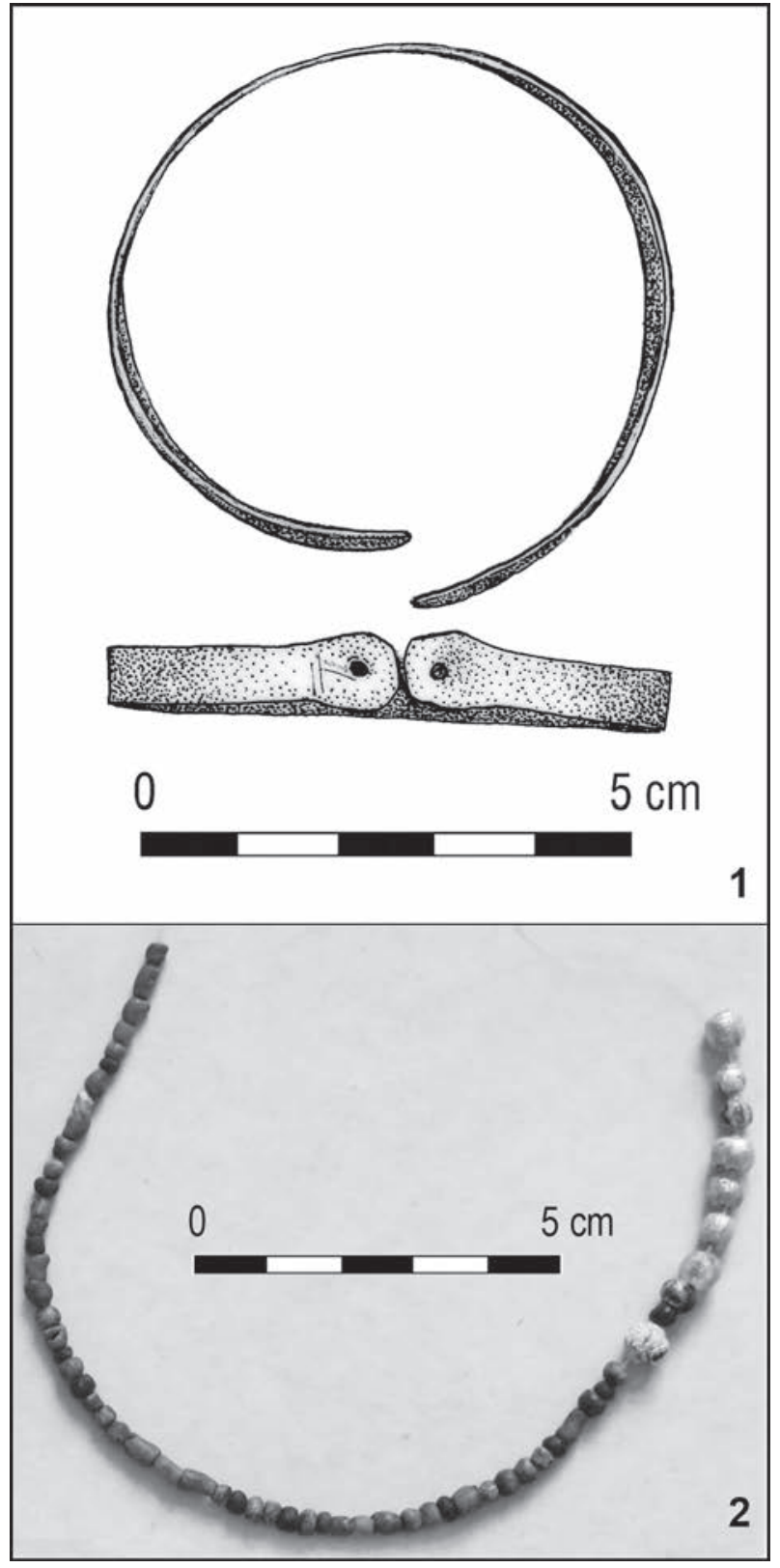

5. kép. 1: Karperec; 2: gyöngyök

Fig. 5. 1: Bracelet; 2: beads

mentést, amelynek során 46 sír került napvilágra. ${ }^{11} \mathrm{Az}$ elmondottak értelmében az ismertetett sírtól északra igen ajánlatos lenne próbaásatást végezni még az építkezés megkezdése előtt. ${ }^{12}$

11 PeTKes 2011.

12 Itt mondunk köszönetet kedves kollégáinknak, akik segítségünkre voltak a sír feltárásában, a leletek dokumentálásában és restaurálásában: Csányi Marietta és Tárnoki Judit régészeknek (Damjanich János Múzeum), Hegedús Sándor fotósnak (Damjanich Múzeum), aki a külső felvételeket készítette, P. Dombóvári Judit főrestaurátornak, aki a tárgyakat restaurálta (Magyar Nemzeti Múzeum), Dabasi Andrásnak (Magyar Nemzeti Múzeum) pedig a korongok fotójáért. 


\section{FÜGGELÉK}

\section{A TISZAPÜSPÖKIBEN 2014-BEN FELTÁRT 10. SZÁZADI NŐI SÍR EMBERTANI FELDOLGOZÁSA}

\section{MARCSIK ANTÓNIA*}

Nő, juvenis (18-20 éves) egyén, jó megtartású, de nagyon hiányos a koponya és a vázcsontok.

Koponya: a homlokcsont szemüreg felé eső része, a jobb oldali állkapocság és a corpus egy része, valamint a bal oldali maxilla maradt meg.

Fogstatus: meglévő fogak: jobb alsó első és második őrlőfog, bal felsó első és második metsző, a többi post mortem hiány.

Vázcsontok: jobb és bal oldali lapocka (a bal teljes, a jobb darabokban), szegycsont markolatrésze, felkarcsontok, bal kulcscsont, bal alkarcsontok, bordák, csigolyák, keresztcsont, bal oldali medence (a jobb oldaliból néhány darab), bal combcsont és alszárcsontok.

Nem meghatározása: a medence morfológiai felépítése alapján (incisura ischiadica major, angulus pubis, sulcius praeauricularis).
Elhalálozási életkor meghatározása: a hosszúcsontok ízületi végeinek nyitottsága, illetve elcsontosodása alapján (felkarcsont felső, alkarcsontok alsó, combcsont felsőalsó, szárkapocs felső fugái nyitottak, keresztcsont szegmentjei félig, a felkarcsont alsó, az alkarcsontok felső fugái és a medencecsontok teljesen zártak). Harmadik jobb alsó őrlőfog csontban.

Morfológiai jellegek: maxilla fogmedri nyúlványa mérsékelten előreálló, a corpus bemélyedése mérsékelt. Felső lateralis metsző medialis „lapát” forma.

Patológiás elváltozás: mindkét szemgödör felső részében mérsékelt (porotikus) felritkulás. A hiányos koponya és vázcsontok metrikus mérésre, taxonómiai megállapításra alkalmatlanok, a szemgödör felritkulása jelentéktelen.

A bordákon, két háti csigolya tövisnyúlványán zöld elszíneződés. **

\section{IRODALOM}

ACSÁDY, GYÖRGY-NEMESKÉRY, JÁNOS

$1970 \quad$ History of human life span and mortality. Budapest.

BENEDEK GYULA

2001 Törökszentmiklós földrajzi helyei. In: Selmeczi L.-Szabó A. (szerk.): Fejezetek Törökszentmiklós múltjából. Törökszentmiklós, 7-88.

CSÁNYI MARIETTA-CSEH JÁNOS-TÁRNOKI JUdIT

2002 Tiszapüspöki, Karancs-Háromág-dúlő: kora bronzkori áldozati gödör és kora vaskori épület (Tiszapüspöki, Karancs-Háromág-dúlő: A sacrificial pit from the early Bronze Age and a building from early Iron Age). In: Kisfaludi J. (szerk.): Régészeti kutatások Magyarországon 1999 (Archaeological Investigations in Hungary 1999). Budapest, 47-62.

DIENES, ISTVÁN

1972 Die Kunst der landnehmenden Ungarn und ihre Glaubenswelt. In: Évolution général et dévelopements régionaux en histoire de l'art. - Actes du XXIIe Congrès International d'Histoire de l'Art. Budapest 1969. Budapest. I, 97-108, III, 39-42.

1980 Der Weltbaum der landnehmenden Ungarn. In: Congressus Quintus Internationalis Fenno-Ugristarum, Budapest 1975. Pars II. Budapest, 202-207.

DiósZegi ViLmos

1969 A honfoglaló magyarság hitvilágának történeti rétegei. A világfa (Die historischen Schichten der Glaubenswelt der Ungarn der Landnahmezeit. Der Weltbaum). Népi kultúra - népi társadalom II-III. Budapest, 295-326.

Éry KingA-KRALOVÁNSZKY AlÁN-NEMESKÉRY JÁNOS

1963 Történeti népességek rekonstrukciójának reprezentációja (A representative reconstruction of historical populations). Anthropológiai Közlemények (Budapest) 7, 41-90.

FODOR IsTVÁN

1970a Tiszapüspöki. Régészeti Füzetek (Budapest) Ser. I. No. 23, 74.

1970b Törökszentmiklós. Régészeti Füzetek (Budapest) Ser. I. No. 23, 20.

\footnotetext{
* Marcsik Antónia. Szegedi Tudományegyetem Embertani Tanszék. 6700 Szeged, Aradi vértanúk tere 1.; marcsik@bio.uszeged.hu

** ÉRY-KralovÁNSZKY-NEMESKÉRY 1963; ACSÁDY-NEMESKÉRY 1970; ORTNER 2003.
} 
1996 Sárospatak-Baksahomok. In: Fodor I. (szerk.): A honfoglaló magyarság. Kiállítási katalógus. Budapest, 168-171.

2014 Honfoglalás kori korongjaink és párhuzamaik (Die altungarische Zierscheiben und ihre Analogien). Folia Archaeologica 56. 133-185.

MADARAS LÁSZLÓ

2003 A szolnok-szandai honfoglalás kori korongpár (Das landnahmezeitliche Scheibenpaar von SzolnokSzanda). Móra Ferenc Múzeum Évkönyve-Studia Archaeologica (Szeged) 9, 277-282.

ORTNER, DONALD. J.

2003 Identification of pathological conditions in human skeletal remains. Amsterdam-Tokyo.

PetKes Zsolt

2011 Törökszentmiklós-Szenttamáspuszta 10-11. századi temetője (Gräberfeld aus dem 10.-11. Jahrhundert von Törökszentmiklós-Szenttamáspuszta). Archaeologiai Értesítő (Budapest) 136, 181-213.

RÉVÉSZ LÁSZLó

2008 Heves megye 10-11. századi temetői (Die Gräberfelder des Komitates Heves im 10.-11. Jahrhundert). Budapest.

SOLYMOSSY SÁNDOR

1933 A vas babonás ereje (Die abergläubische Kraft des Eisens). Ethnographia (Budapest) 44, 97-117.

\section{A CONQUEST PERIOD BURIAL ON THE OUTSKIRTS OF TISZAPÜSPÖKI}

\section{ISTVÁN FODOR-RÓBERT KERTÉSZ}

A 10th-century female burial of the Hungarian Conquest period came to light on the south-eastern outskirts of Tiszapüspöki lying on the left bank of the Tisza, north of Szolnok, in the immediate vicinity of Törökszentmiklós, during the salvage excavations preceding the construction of the M4 Motorway (Fig. 1). The west-oriented burial of the young woman was disturbed: the skull and the right side of the skeleton were dislodged from their original position (Fig. 2).

The two tinned bronze braid ornaments lying on top of one another, which had originally been plaited into the braids by means of leather or textile ribbons, came to light from under the vertebrae. The braids had been unbraided before the funeral and the braid ornaments had been placed on the grave floor together with the other grave goods. The openwork ornaments decorated with a vegetal design unfurling from a three-leaved palmette bunch, were cast from the same mould. However, the workmanship of the two discs differs: the disc worn in the right braid was crafted more carefully, the left one more carelessly, suggesting that the two had not been made at the same time and that they had perhaps not even been produced by the same craftsman (Fig. 4).
A bronze bracelet with widening oval terminals was found on left lower arm. The two ends of the bracelet were perforated for fastening the two ends to each other (Fig. 3.2, Fig. 5.1). The bracelets found in the 10th-century female burials of the Conquest period usually lay in the middle of the arm: they were used for gathering the loose sleeve.

Fifty-two clay beads (diam. $0.2-0.3 \mathrm{~cm}$ ) and eight cowry beads (diam. $0.5 \mathrm{~cm}$ ) were found on the left shoulder and the left side of the chest.

The most remarkable item among the grave goods is the pair of braid ornaments, which can be assigned to the group bearing a Tree of Life design among the openwork braid ornaments of the 10th century. The design was conceived in a distinctive ancient Hungarian style. The currently known similar braid ornaments were without exception produced in the Carpathian Basin and they can therefore hardly be dated to the early 10th century. At the same time, the pagan religious associations of their design means that they could not have been made towards the end of the century - the braids were made sometime between these two dates, which is not contradicted by the other grave goods recovered from the burial. 